Discussion Papers in Economics

\title{
Has India Emerged? Business Cycle Stylized Facts from a Transitioning Economy
}

\author{
Chetan Ghate
}

Radhika Pandey

Ila Patnaik

May 2011

Discussion Paper 11-05

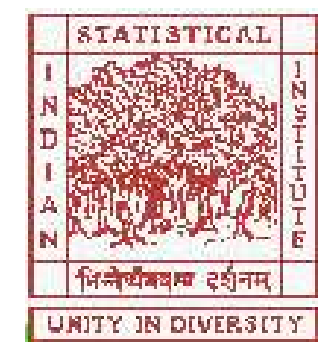

Indian Statistical Institute, Delhi

Planning Unit

7, S. J. S. Sansanwal Marg, New Delhi 110016, India 


\title{
Has India Emerged? Business Cycle Stylized Facts from a Transitioning Economy
}

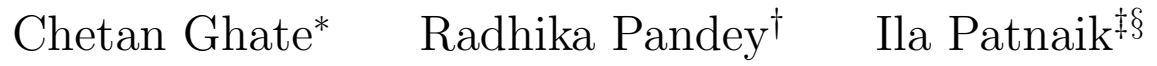

April 27, 2011

\begin{abstract}
This paper presents a comprehensive set of stylised facts for business cycles in India from 1950 - 2009. We find that the nature of the business cycle has changed dramatically after India's liberalisation reforms in 1991. In particular, after the the mid 1990s, the properties of India's business cycle has moved closer in key respects to select advanced countries. This is consistent with India's structural transformation from a pre-dominantly agricultural and planned developing economy to a more market based industrial-income economy. We also identify in what respects the behaviour of the Indian business cycle is different from that of other advanced economies, and closer to that of other less developed economies. This is the first exercise of this kind to generate an exhaustive set of stylised facts for India using both annual and quarterly data.
\end{abstract}

JEL Classification: E10, E32

Keywords: Macroeconomics, Real Business Cycles, Emerging Market DSGE Models, Volatility and Growth.

*Corresponding Author: Chetan Ghate, Planning Unit, Indian Statistical Institute, New Delhi, 110016, India. E-mail: cghate@isid.ac.in. Fax: 91-11- 4149-3981. Tel: 91-114149-3981.

$\dagger$ Email:radhesp@gmail.com

‡Email:ilapatnaik@gmail.com

$\S$ This paper was written under the aegis of the SPF Financial and Monetary Policy Reform Project at the National Institute for Public Finance and Policy, New Delhi. We are grateful to Abhijit Banerjee for comments. We also thank participants at the 'Business Cycle Facts and DSGE Model for India' workshop at NIPFP, the Eighth meeting of the NIPFP-DEA Research Program, and Workshop 5 of the Center for International Macroeconomic Studies (Surrey University) for useful comments. 


\section{Contents}

\begin{tabular}{lll}
\hline 1 & Introduction & 3
\end{tabular}

\begin{tabular}{|lll}
2 & Stylised Facts from Emerging Economies & 6
\end{tabular}

$\begin{array}{lll}3 & \text { India in Transition } & 9\end{array}$

$\begin{array}{lll}4 & \text { The Dataset } & 12\end{array}$

$\begin{array}{lll}5 & \text { Statistical Methodology } & 13\end{array}$

6 Indian Business Cycle Stylised Facts in the Pre and Post

$\begin{array}{lll}7 & \text { Robustness Checks } & 18\end{array}$

7.1 Stylised Facts with Quarterly Data . . . . . . . . . . . . . . . 18

7.2 An Alternative Detrending Method . . . . . . . . . . . . . . . 22

7.3 Redefining the Sample Period . . . . . . . . . . . . . . . . 23

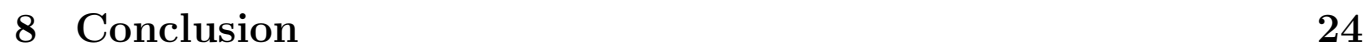

\begin{tabular}{|lr|}
\hline A Data Definition and Sources & 29
\end{tabular} 


\section{Introduction}

This paper describes the changing nature of the Indian business cycle from 1950 - 2009. Our focus is to compare India's business cycle in the pre 1991 economy, with the post 1991 Indian economy, after the large scale liberalization reforms of 1991. Our main finding is that after the liberalisation of the Indian economy in 1991, the properties of the Indian business cycle look closer to that of advanced industrialized economies in several key respects. This paper - to the best of our knowledge - is the first such exercise to comprehensively document changes in the properties of the Indian business cycle in the pre and post reform period.

A large literature documents business cycle stylised facts both in advanced industrial economies (Kydland and Prescott, 1990; Backus and Kehoe, 1992; Stock and Watson, 1999; King and Rebelo, 1999) as well as developing and emerging market economies (Agenor et al., 2000; Rand and Tarp, 2002; Male, 2010). Agenor et al. (2000) present a comparison of the business cycle properties of developed and developing economies based on a quarterly dataset from first quarter of 1978 to the fourth quarter of 1995. The Index of industrial production (IIP) is taken as a proxy for aggregate business activity. Cyclical components of variables are derived using both the HodrickPrescott and Baxter-King filters. A main finding of the paper is that developing economies are characterized by higher output volatility compared to developed economies. Similarly, Rand and Tarp (2002) report business cycle stylised facts for 15 developing economies based on an annual dataset from 1970-1997. GDP is taken as a proxy for aggregate business activity. These authors find that output volatility in developing economies is $15-20 \%$ higher than that of developed countries. They also find that consumption is more volatile than output for developing economies (with South Africa and India as exceptions). Volatility in investment is found to be similar to developed economies. However, they do not find any consistent evidence of countercyclical government expenditure in their sample of developing economies 11

Other papers in the literature - such as Neumeyer and Perri (2005) - also provide a comparison of business cycle properties of a set of five emerging economies with a set of five developed economies. GDP is taken as a proxy for

\footnotetext{
${ }^{1}$ Rand and Tarp (2002) find a positive relation between consumption and output except for Nigeria. Higher volatility in investment is found to be pro-cyclical in all the developing countries included in the sample. While imports are reported to be pro-cyclical, the picture regarding exports is unclear. On the relation between price level and output, the picture is unclear with seven of the developing economies reporting significant negative correlation between price level and output.
} 
aggregate business cycle activity. Output volatility is found to be higher for emerging economies. While the relative volatility of consumption is greater than 1 for emerging economies, the relative volatility of investment is uniform across the two set of countries. Similarly, Alper (2002) analyses business cycles in Mexico and Turkey from 1987-2000 and presents a comparison of the results with the United States. Consistent with the business cycle features of developing economies, the volatility of real GDP in Mexico and Turkey are found to be 2.63 and 3.91 times larger than for the United States. Consumption is found to be more volatile than output in these economies.

Finally, Male (2010) provides a comprehensive documentation of cross-country comparison of business cycle stylised facts. Her paper relies on a quarterly dataset for 32 developing economies, across different regions, of which India is part of the sample for Asian countries. Due to lack of reliable data on real GDP for a number of developing economies, she uses indexes of industrial production as a proxy for the aggregate business cycle. Business cycle properties of developing economies are found to be distinctly different from those of developed economies. Key variables like output, private consumption, price levels are more volatile in developing economies. The correlation of investment and imports with the aggregate business cycle is not found to be very strong. Government expenditure is not significantly counter-cyclical, unlike in developed countries. Business cycle characteristics also differ in terms of persistence of variables. For instance, the persistence of output and price levels are lower for developing economies compared with developed economies.

Because India is typically treated as one of many countries within a larger sample (see (Agenor et al., 2000; Rand and Tarp, 2002; Male, 2010)), such studies do not show the changing nature of the business cycle of any particular country over time. Our main contribution is to provide evidence on the changing stylised facts of the Indian economy from 1950 - 2009. During this time, India transitioned from a closed and protected economy characterised by controls on capacity creation and high import duties, to an economy well integrated with the world, with the policy environment changing significantly in 1991. In terms of business cycle fluctuations, the economy moved away from monsoon cycles (Patnaik and Sharma, 2002) to business cycles in the conventional sense.

The empirical literature on stylised facts relies on long time series of quarterly data. However, quarterly GDP data in India is available only from 1999. This limits us to 11 years of quarterly data for our key variables. Hence, since we are interested in the changing pattern of the Indian business cycle, we 
conduct our analysis with annual data and then use the quarterly data to check the robustness of our results.

In particular, we are interested in the properties of Indian business cycle over two periods: 1950-1991 for the pre-liberalisation period and 1992-2009 for the post-liberalisation period. GDP, private consumption, total gross fixed capital formation, consumer prices, exports, imports, government expenditure and nominal exchange rate are the key variables analysed. Since the quantitative general equilibrium literature also seeks to explain the strong counter-cyclicality of net exports as well as highly volatile and counter cyclical interest rates in emerging markets, we also report the business cycle properties of these variables for India. Our main finding is to highlight the difference in the properties of the Indian business cycle stylised over the two periods, and suggest reasons for these changes. A data appendix lists all the sources and definitions of variables used in this study.

In terms of similarities, we find that output (Real GDP) has become less volatile in the post-liberalisation period; investment has become significantly pro-cyclical in the post-liberalisation period; the correlation of imports with GDP has also increased; net exports have become counter-cyclical; the volatility in prices and government expenditure has decreased in the post liberalisation period; and the absolute volatility in nominal exchange rate has declined. Further, our results using quarterly data are consistent with the findings of the annual data analysis for the post 1991 period. This suggests that in many key respects, the Indian business cycle shows a growing resemblance with those of the developed economies.

In terms of differences, the Indian business cycle features also resemble features of developing economies. While output volatility has fallen, it still remains high. In addition, consumption is more volatile than output. Further, government expenditure is not strongly counter-cyclical with respect to output, as in advanced economies.

In terms of the sensitivity tests, we note that the volatility of consumption is sensitive to the choice of the de-trending procedure. The absolute volatility of private consumption falls in the post-reform period when the band pass filter of Baxter-King is used to de-trend the series. However, the absolute volatility is higher in the post-reform period when the Hodrick-Prescott filter is used to de-trend the series. There is also a significant reduction in volatility of government expenditure when the Baxter-King filter is used to de-trend the series. However, the key feature of the Indian business cycle which is robust to de-trending procedures is the significant pro-cyclicality of investment with output. Coupled with the increased pro-cyclicality of imports with output, 
this feature makes the Indian business cycle stylised facts closer to those of the advanced economies.

The remainder of the paper is divided into the following sections. Section 2 outlines the main features of emerging economies business cycle with an overview of the sources of shocks in these economies. Section 3 presents a snapshot of India's transition. Section 4 outlines the data sources and the variables included in the study. Section 5 details the methodology employed to compute the Indian business cycle stylised facts. Section 6 provides empirical evidence on the changing Indian business cycle stylised facts from pre to post reform period. Section 7 presents results on sensitivity tests. Section 8 concludes.

\section{$2 \quad$ Stylised Facts from Emerging Economies}

As noted in the introduction, one of the main features that distinguishes emerging economies business cycles from advanced economies is their higher volatility. Current account balances, output growth, interest rates, and exchange rate tend to exhibit larger, and more frequent changes (Calderón and Fuentes, 2006). There are other aspects that characterize emerging market economies: consumption is more volatile than output with a relative volatility larger than one; real interest rates are highly volatile and counter cyclical, and net exports are strongly counter-cyclical (Neumeyer and Perri, 2005; Aguiar and Gopinath, 2007; Uribe and Yue, 2006) .2

As a point of reference, we reproduce Table 1 from Aguiar and Gopinath (2007) ? $^{3}$ The analysis covers 13 developed and 13 emerging economies based on a quarterly dataset $4^{4}$ The findings in Table 1 are broadly consistent with

\footnotetext{
${ }^{2}$ Empirical work on emerging market business cycles has led to quantitative general equilibrium models both in the RBC and DSGE tradition on understanding the key properties of emerging market business cycle fluctuations (Aguiar and Gopinath, 2007, Chakraborty, 2008, Neumeyer and Perri, 2005, Uribe and Yue, 2006; Batini et al., 2010. Gabriel et al. 2010; Garcia-Cicco et al. 2010).

${ }^{3}$ We refer to this paper as it provides average figures for business cycle characteristics for developed and developing economies. This facilitates locating the position of Indian business cycle vis-a-vis developed and developing economies.

${ }^{4}$ Australia, Austria, Belgium, Canada, Denmark, Finland, Netherlands, New Zealand, Norway, Portugal, Spain, Sweden and Switzerland comprise the sample of developed economies while Argentina, Brazil, Ecuador, Israel, Korea, Malaysia, Mexico, Peru, Philippines, Slovak Republic, South Africa, Thailand and Turkey comprise the set of emerging economies.
} 
the findings of other papers on the business cycle stylised facts of developing economies.

Table 1 Business cycle statistics for developed and emerging economies using quarterly data

\begin{tabular}{lcccccc}
\hline & \multicolumn{3}{c}{ Developed economies } & \multicolumn{3}{c}{ Emerging economies } \\
\hline & $\begin{array}{c}\text { Std } \\
\text { dev. }\end{array}$ & $\begin{array}{c}\text { Rel } \\
\text { std. dev. }\end{array}$ & $\begin{array}{c}\text { Cont. } \\
\text { cor. }\end{array}$ & $\begin{array}{c}\text { Std } \\
\text { dev. }\end{array}$ & $\begin{array}{c}\text { Rel. } \\
\text { std. dev. }\end{array}$ & $\begin{array}{c}\text { Cont. } \\
\text { cor. }\end{array}$ \\
\hline Real GDP & 1.34 & 1.00 & 1.00 & 2.74 & 1.00 & 1.00 \\
Private Consumption & & 0.94 & 0.66 & & 1.45 & 0.72 \\
Investment & & 3.41 & 0.67 & & 3.91 & 0.77 \\
Trade balance & & 1.02 & -0.17 & & 3.22 & -0.51 \\
\hline Source: Aguiar and Gopinath, 2007. & & & & & \\
\hline
\end{tabular}

Table1 shows that the business cycle characteristics of developed and emerging economies differ on some important dimensions. Emerging economies, on an average have higher output volatility compared with the developed economies. Table 1 shows an average volatility of 1.34 for developed economies and 2.74 for emerging economies. Another important difference is that consumption tends to be more volatile than output in emerging economies. The average relative volatility of consumption is 1.45 for emerging economies and 0.94 for developed economies. Relative investment volatility is comparatively higher for emerging economies at 3.91, compared to 3.41 for developed economies.

A distinguishing feature of emerging economies business cycle is the strong counter-cyclicality of trade balance at the business cycle frequencies. According to Aguiar and Gopinath (2007), this property follows from the nature of shocks governing fluctuations in developed and emerging economies. The productivity processes can be in the form of a transitory shock around the trend growth rate of productivity and a stochastic trend growth rate. In an emerging market setting, a shock to the growth rate implies a boost to current output, but an even larger boost to future output. This implies that consumption responds more than income, reducing savings and generating a current account deficit. If growth shocks dominate transitory income shocks, the economy resembles a typical emerging market with its volatile consumption process and counter-cyclical current account. Conversely, a developed economy characterised by relatively stable growth process will be dominated by standard, transitory productivity shocks. Such a shock will generate an incentive to save that will offset any increase in investment, resulting in limited cyclicality of the current account. However, counter-cyclical net exports 
is also reported for developed economies by Stock and Watson (1999); Rand and Tarp (2002).

Aguiar and Gopinath (2007) use a standard RBC model to explain the business cycle properties of emerging markets. Because emerging market economies are characterized by frequent changes in economic policy, they assume that shocks to trend growth are the primary source of fluctuations. This implies that the random walk component of the Solow residual is relatively larger. However, Calderón and Fuentes (2006) suggest that because the sources of shocks in Aguiar and Gopinath (2007) remain a black box, it is not clear whether these are being driven by changes in economic reforms, or other market frictions. Indeed, Chari et al. (2007) show that a variety of frictions can be represented in reduced form as Solow residuals. Garcia-Cicco et al. (2010) show that when estimated over a long sample, the RBC model driven by permanent and transitory shocks - a la Aguiar and Gopinath (2007) - does a poor job in explaining observed business cycles in Argentina and Mexico, along a number of dimensions. These findings of Garcia-Cicco et al. (2010) suggest that the RBC model driven by productivity shocks does not provide an adequate explanation of business cycles in emerging economies.

Other papers in the literature, such as Neumeyer and Perri (2005) emphasize the interaction between foreign interest rate shocks and domestic financial frictions that drive business cycle fluctuations in emerging market economies. Firms in their model demand working capital to finance their wage bill making labour demand sensitive to interest rate fluctuations. An increase in the emerging market country's interest rate leads to a rise in labour costs. Since labour supply is insensitive to interest rate shocks, a lower demand for labour leads to lower levels of employment and output in equilibrium. Uribe and Yue (2006) find that both country interest rates drive output fluctuations in emerging market economies as well as the other way around. Kose et al. (2003) analyse the importance of domestic and external factors as causing cycles. Calvo (1998) argues that the idea of sudden stops are an important factor of large cycles in emerging markets.

A discussion of the sources of aggregate business cycle fluctuations assumes greater relevance for a country like India that has undergone significant transformation since the early nineties. With high growth, there has been a sharp increase in India's integration on both trade and financial flows, possibly leading to one source of volatility $\left.\right|^{5}$ Ramey and Ramey (1995) however find, that

\footnotetext{
5 Jayaram et al. (2009) show that the integration with the global economy has also resulted in greater business cycle synchronisation with advanced economies and with the US.
} 
there is a negative correlation between volatility and growth. This would suggest that whether India's output is more volatile (compared to OECD economies), because it is growing faster, would seem unlikely, unless growth has increased volatility and volatility itself reduces growth subsequently. We therefore think a plausible story of the changing pattern of the Indian business cycle is to link it with the policy regime. In particular, prior to 1991, positive productivity shocks could not be accommodated and generated inflationary pressures and a worsening of the exchange rate. After the 1991 reforms, the same shocks were permitted to generate growth, making investment and imports go up, with foreign investment flowing in and the exchange rate appreciating. As in Aguiar and Gopinath (2007), consumption volatility remained high mostly because of permanent productivity shocks, i.e., consumption volatility was driven by shocks to income that are larger or more persistent than they should be. However, the focus of this paper is in documenting the changing nature of the Indian business cycle in the pre and post reform period $]^{6}$

\section{India in Transition}

As mentioned earlier, a careful analysis of business cycle stylised facts assume greater relevance for an economy like India that is subject to significant transformation over the last two decades. In this section, we present some of the key elements of transformation in the Indian economy from 1950 - 2009.

1. Reduction in the consumption-output ratio: The first two plots of Figure 1 show the behaviour of the consumption-output ratio and investment output ratio from 1950-2009. The graphs show that while the share of private consumption has declined, there is a gradual and consistent increase in the share of investment in GDP.

\footnotetext{
${ }^{6}$ Another source of volatility would be that productivity shocks get amplified by frictions as in (Aghion et al. 2004$)$. Here, excess output volatility results because of capacity under-utilization. Aghion et al. (2010) show however that there is not much evidence that investment responds more to productivity shocks in economies with less good capital markets. On the other hand, these authors also find that the fraction of long term investment in total investment is more pro-cyclical in economies with less good capital markets. If long run investment enhances productivity, then the reform story implicit in this paper acquires salience.
} 

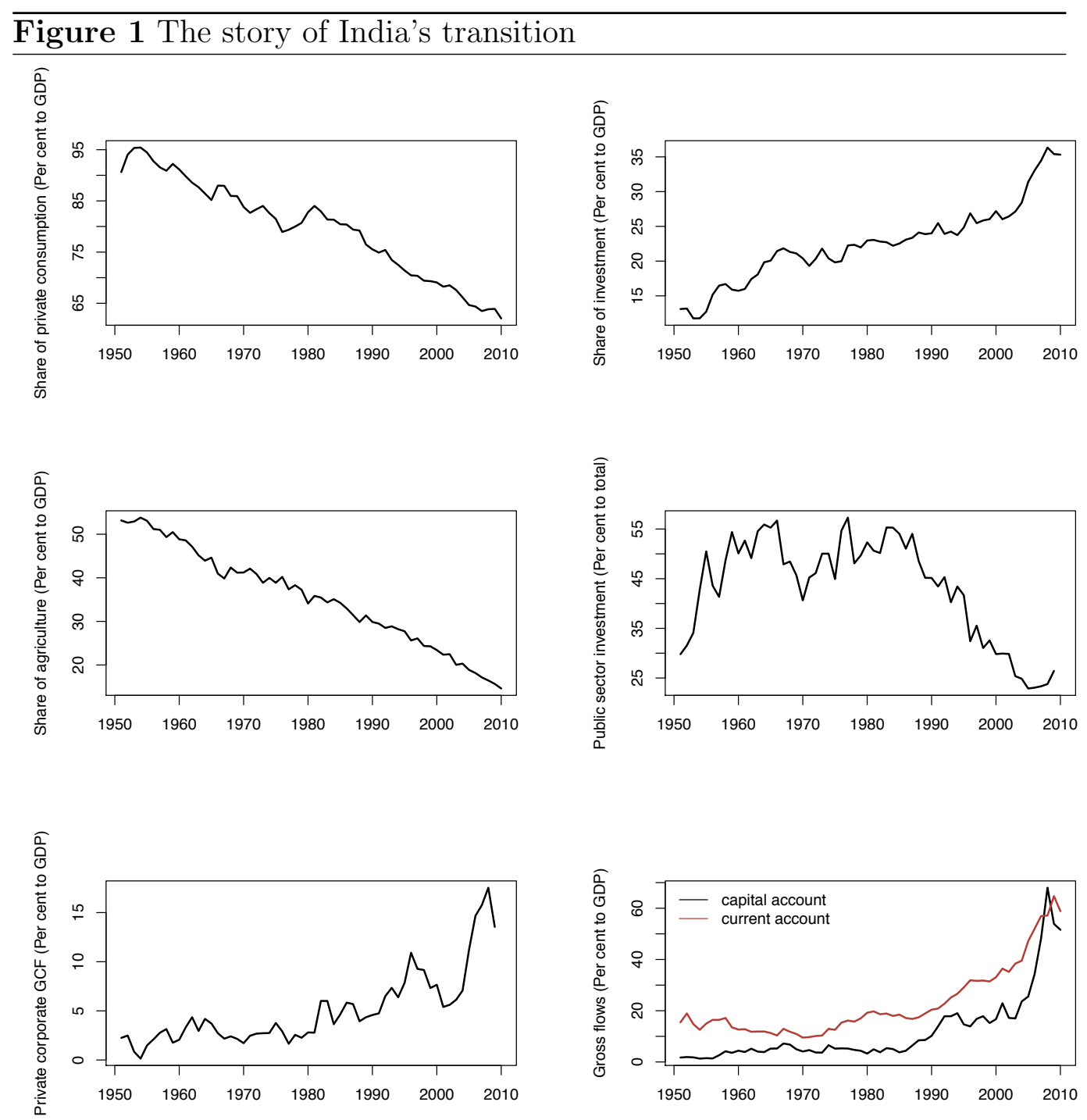

In addition, since the mid 1990s, the Indian economy has undergone a significant transformation in many aspects. From a purely monsoon driven economy, fluctuations in the economy are now driven primarily by fluctuations in inventory and investment. The share of investment in GDP has increased from $13 \%$ in $1950-51$ to $35 \%$ in $2009-10$. The increase has been particularly prominent since 2004-05.

2. Declining share of agriculture: In the India of old, monsoon performance used to define a good or bad time. Adverse agricultural performance used to throw GDP growth off trend (Shah, 2008; Patnaik and 
Sharma, 2002). In the India of present times, monsoon shocks matter less. This is evident in the declining share of agriculture in Indian GDP. The third graph in Figure 1 shows a consistently declining share of agriculture since 1950s. Table 2 shows the changing composition of Indian GDP, the decline in the share of agriculture has been matched with a rise in the share of services.

\begin{tabular}{|c|c|c|c|}
\hline & Agriculture & Industry & Services \\
\hline 1951 & 53.15 & 16.5 & 30.2 \\
\hline 1992 & 28.8 & 27.4 & 44 \\
\hline 2009 & 14.6 & 28.4 & 57 \\
\hline
\end{tabular}

3. Shift away from state domination: An important dimension of India's transition is the shift away from state domination towards a market economy. This is visible in the fourth graph of Figure 1. The graph shows that the share of public investment in total investment surged in the 1960s and 1970s. Since then it has been consistently declining.

4. Emergence of a conventional business cycle: The policy set up in India of old times was characterised by controls on capacity creation and barriers to trade. In such a scenario, conventional business cycles characterised by an interplay of inventories and investment did not exist. One prominent source of investment was government investment in the form of plan expenditure, which did not show any cyclical fluctuations. In the present environment with eased controls on capacity creation and dismantling of trade barriers, private sector investment as a share of GDP has shown a significant rise.

The fifth graph in Figure 1 shows the time series of private corporate gross capital formation expressed as a percent to GDP. In recent years we can see the emergence of the behaviour found in the conventional business cycle. In the investment boom of the mid-1990s, private corporate GCF rose from 5\% of GDP in 1990-91 to 11\% of GDP in 1995-96. This then fell dramatically in the business cycle downturn to $5.39 \%$ in 2001-02, and has since recovered to $17.6 \%$ in 2007-08. The recent recession has led to its fall to $13.5 \%$ in $2009-10$.

5. Increased integration with the rest of the world: The India of old was sheltered from external competition through high import duties and other barriers to trade. The capital account was also subject to strict 
regulations on inflows and outflows. Since the adoption of liberalisation policy, the restrictions on current and capital account have been eased. This has resulted in India moving away from an autarky situation.

An effective way of measuring the openness is to sum the earnings and payments on the current and capital account and express the sum as a percent to GDP. The last graph in Figure 1 shows the time series of current and capital account flows expressed as a percent to GDP. In the pre-reform period the flows on current and capital account were around $20 \%$ of GDP. The conducive policy environment has resulted in both current and capital account flows to GDP ratio rising to around $60 \%$ each in 2009.

\section{The Dataset}

We now undertake a formal analysis of Indian business cycle stylised facts. In India, quarterly data for output and key macroeconomic variables is available only from June 1999. To understand the changing nature of Indian business cycles, we examine annual data. We then check the validity of our results with quarterly data. This is consistent with the literature on stylised facts (King and Rebelo, 1999: Stock and Watson, 1999; Male, 2010), that relies on quarterly data to study business cycle properties of macroeconomic variables. Following (King and Rebelo, 1999) we choose private consumption and investment as key variables. In addition, we analyze exports, imports, net exports, consumer prices (Consumer Price Index-Industrial Worker (CPI-IW)) 7 , government expenditure and the nominal exchange rate. Data on hours worked, real wage rate and total factor productivity is not available for India. We use GDP as a measure of aggregate activity in the economy.

For the annual analysis, we have a sample period covering 1950-2009. To study the transition of the economy, the data is analyzed in two periods: the pre-liberalisation period from 1950-1991 and the post liberalisation period from 1992 to 2009. The primary data source is the National Accounts Statistics of the Ministry of Statistics and Programme Implementation. The data for consumer prices is taken from the Labour Bureau, Ministry of Labour and Employment. The data for government expenditure is taken from the budget documents of the Government of India. GDP, private consumption, gross fixed capital formation, exports and imports are expressed at constant

\footnotetext{
${ }^{7}$ In most countries the headline inflation number is consumer prices, in India it is wholesale prices. We follow the literature on stylised facts in using consumer prices.
} 
prices with base 2004. Government expenditure is expressed in real terms by deflating it with the GDP deflator. Following (Agenor et al., 2000) and (Neumeyer and Perri, 2005) net exports is divided by real GDP to control for scale effects. We source the data from the Business Beacon database produced by the Centre for Monitoring Indian Economy (CMIE), who source it from the primary data sources mentioned above. All variables and their sources are described in detail in the Appendix.

For their analysis of investment, King and Rebelo (1999) use only the fixed investment component of gross domestic private investment. The other components of gross domestic private investment are residential and non-residential investment. The volatility of gross domestic private investment in the US is higher than the component of fixed investment as residential investment is highly volatile. We take gross fixed capital formation as a proxy for investment since unlike the US, we do not have data on the categories of gross investment.

The variables analyzed are log transformed. The cyclical components of these variables are obtained from the Hodrick-Prescott filter, as is standard in the literature (King and Rebelo, 1999; Agenor et al., 2000; Neumeyer and Perri, 2005). The cyclical components are then used to derive the business cycle properties of the variables in terms of their volatility and co-movement. For the sensitivity analysis, we test the robustness of our results by using the band-pass filter of Baxter-King (Agenor et al., 2000). As a further check, we also use quarterly data to verify the validity of our results.

\section{$5 \quad$ Statistical Methodology}

The business cycles examined in the literature are typically known as growth cycles, extending from the work of (Lucas, 1977) where the business cycle component of a variable is defined as its deviation from trend 8 We follow this standard methodology in deriving the stylised facts for Indian business cycles.

For annual data analysis, the log transformed series is passed through a filter to extract the cyclical (stationary) and trend (non-stationary) component.

\footnotetext{
${ }^{8}$ Business cycles dating goes back to the early work by (Burns and Mitchell, 1946$)$. The classical approach propounded by (Burns and Mitchell, 1946) defines business cycles as sequences of expansions and contractions in the levels of either total output or employment. In 1990, (Kydland and Prescott, 1990) established the first set of stylised facts for business cycles in other developed economies, based on their research of US business cycle.
} 
In case of quarterly data, the variables are adjusted for seasonal fluctuations using the X-12-ARIMA seasonal adjustment program 9 Once adjusted for seasonality, the series are transformed to log terms and then filtered to extract the cyclical and trend component.

A large literature exists on the choice of the de-trending procedure to extract the business cycle component of the relevant time series (Canova, 1998; Burnside, 1998; Bjornland, 2000). Canova (1998) argues that the application of different de-trending procedures extract different types of information from the data. This results in business cycle properties differing widely across de-trending methods. However, commenting on (Canova, 1998), Burnside (1998) shows through spectral analysis, that the business cycle properties of variables are robust to the choice of the filtering methods if the definition of business cycle fluctuations are uniform across all the de-trending methods.

In choosing the technique to derive the cyclical component, the literature on stylised facts mainly relies on either the Hodrick-Prescott filter (King and Rebelo, 1999; Male, 2010) or the band-pass filter proposed by Baxter and King (Stock and Watson, 1999). We use the Hodrick-Prescott filter (Hodrick and Prescott, 1997) to de-trend the series and then check the robustness of our results with the Baxter-King filter (Baxter and King, 1999).

In essence, the Hodrick-Prescott method involves defining a cyclical output $y_{t}^{c}$ as current output $y_{t}$ less a measure of trend output $y_{t}^{g}$ with trend output being a weighted average of past, current and future observations:

$$
y_{t}^{c}=y_{t}+y_{t}^{g}=y_{t}-\sum_{J=-j}^{J} a_{j} y_{t-j}
$$

After de-trending the series to obtain the cyclical components, we can then determine the properties of the business cycle. In the subsequent analysis, all references to the variables refer to their cyclical component. The cyclical component of the variable is used to derive the volatility and co-movements of variables.

Our definition of these terms is standard in the literature. Volatility is a measure of aggregate fluctuations in the variable of interest. It is measured by the standard deviation of the variable. Relative volatility is the ratio of volatility of the variable of interest and the variable used as a measure

\footnotetext{
${ }^{9}$ We have set set up a website, www.mayin.org/cycle.in/ which has seasonally adjusted data for key Indian monthly and quarterly time-series. This data is updated every Monday.
} 
of aggregate business cycle activity. A relative volatility of more than one implies that the variable has greater cyclical amplitude than the aggregate business cycle. The degree of co-movement of a variable of interest $y_{t}$ with the measure of aggregate business cycle $x_{t}$ is measured by the magnitude of correlation coefficient $\rho(j)$ where $j$ refers to leads and lags (Agenor et al. 2000). The variable is considered is considered to be pro-cyclical if the contemporaneous coefficient $\rho(0)$ is positive, a-cyclical if the contemporaneous coefficient $\rho(0)$ is zero and counter-cyclical if the contemporaneous coefficient $\rho(0)$ is negative.

\section{Indian Business Cycle Stylised Facts in the Pre and Post Reform Period}

Table 3, which constitutes the main finding of this paper shows the changing nature of the Indian business cycle from 1950 - 2009.

Table 3 Business cycle statistics for the Indian economy using annual data: Pre and post reform period

\begin{tabular}{lcccccc}
\hline \hline & \multicolumn{3}{c}{ Pre-reform period } & $(1950-1991)$ & \multicolumn{3}{c}{ Post-reform period } & $(1992-2009)$ \\
\hline & $\begin{array}{c}\text { Std. } \\
\text { dev. }\end{array}$ & $\begin{array}{c}\text { Rel. } \\
\text { std. dev. }\end{array}$ & $\begin{array}{c}\text { Cont. } \\
\text { cor. }\end{array}$ & $\begin{array}{c}\text { Std. } \\
\text { dev. }\end{array}$ & $\begin{array}{c}\text { Rel. } \\
\text { std. dev. }\end{array}$ & $\begin{array}{c}\text { Cont. } \\
\text { cor. }\end{array}$ \\
\hline Real GDP & 2.13 & 1.00 & 1.00 & 1.78 & 1.00 & 1.00 \\
Pvt. Cons. & 1.82 & 0.85 & 0.69 & 1.87 & 1.05 & 0.89 \\
Investment & 5.26 & 2.46 & 0.22 & 5.10 & 2.85 & 0.77 \\
CPI & 5.69 & 2.66 & 0.07 & 3.49 & 1.95 & 0.29 \\
Exports & 7.14 & 3.34 & 0.07 & 7.71 & 4.31 & 0.33 \\
Imports & 11.23 & 5.26 & -0.19 & 9.61 & 5.38 & 0.70 \\
Govt expenditure & 6.88 & 3.22 & -0.35 & 4.60 & 2.58 & -0.26 \\
Net exports & 0.9 & 0.4 & 0.24 & 1.1 & 0.65 & -0.69 \\
Nominal exchange rate & 6.74 & 3.15 & 0.10 & 5.35 & 3.00 & -0.48 \\
\hline
\end{tabular}

The main features can be summarized as follows:

- Volatility of macroeconomic variables: High macroeconomic volatility is considered both a source as well as reflection of underdevelopment (Loayza et al. 2007 ). The volatility statistics of the key macroeconomic variables present a mixed picture. The aggregate GDP has seen a decline in volatility from 2.13 in the pre-reform period to 1.78 in the post-reform period. This is due to a decline in volatility in the agricultural component of GDP. The volatility of the agricultural GDP has 
fallen to half from 4.26 in the pre-reform period to 2.56 in the postreform period due to better agricultural performance. The volatility of investment has declined from 5.26 in the pre-reform period to $5.10 \mathrm{in}$ the post-reform period. Consumer prices, imports, government expenditure and nominal exchange rate have also become less volatile in the post-reform period. However the fall in volatility is not common to all the macroeconomic variables that we consider. Private consumption and exports have seen a marginal increase in volatility from 1.82 to 1.87 and 7.14 to 7.71 respectively in the post-reform period.

- Increased pro-cyclicality of investment with output: A significant feature of modern capitalist economies is that investment is highly procyclical vis-a-vis the aggregate business cycle. Table 3 reports a significant increase in contemporaneous correlation of investment with output from 0.22 in the pre-reform period to 0.60 in the post reform period.

- Increased pro-cyclicality of imports with output: Imports have become pro-cyclical in the post-reform period. The external sector policies in the pre-reform period were based on protectionism and import licensing. This is reflected in a negative correlation of imports with output in the pre-reform period. The policy thinking underwent a major change in post 1991 period. Tariff barriers were reduced and non-tariff barriers were dismantled in the mid 1990s. The demand for raw material imports increased substantially with easing of capacity controls on industries. This resulted in imports fluctuating with changes in aggregate business activity. Table 3 shows an increase in the contemporaneous correlation of imports from an insignificant -0.19 in pre-reform period to 0.70 in post-reform period. The pro-cyclical nature of imports is again a feature similar to those for advanced open economies.

- Counter-cyclical nature of net exports: Since imports are significantly pro-cyclical and exports are not highly correlated with GDP, on balance this leaves us with a counter-cyclical nature of net exports. Table 3 shows a transition from a-cyclicality in net exports to counter-cyclical net exports.

- Counter-cyclicality of nominal exchange rate: The nominal exchange rate has turned counter-cyclical in the post-reform period. From an acyclical relation in the pre-reform period, the post-reform period shows that the exchange rate goes up in bad times and moves down in good times. This is indicative of the presence of a flexible exchange rate regime in the post-91 period. 
Hence, in several key respects, the features of the Indian business cycle have undergone a transformation and have converged to those of advanced economies. Investment and imports are found to be strongly correlated with output in the post-reform period. Net exports and nominal exchange rate are found to be strongly counter-cyclical in the post-reform period.

Finally, following (Ambler et al., 2004), we investigate whether our correlation results are mere statistical noise or are robust to procedures for testing the statistically significant difference in correlation 10

Table 4 shows the difference in correlation and the associated p-value. The application of the test shows that the difference in correlation between the pre and post-reform period is statistically significant for investment, imports, net exports and the nominal exchange rate. These are the variables that drive the transition in the economy from the pre to post reform period. As an example, these results imply that the difference in the cyclical relation between, say, investment and output, is statistically significant between the pre and post reform period.

\footnotetext{
${ }^{10}$ The procedure for testing the statistically significant difference in correlation involves the following steps:
}

- Let $r_{1}$ be the correlation between the two variables for the first group with $n_{1}$ subjects.

- let $r_{2}$ be the correlation for the second group with $n_{2}$ subjects.

- To test $H 0$ of equal correlations we convert $r_{1}$ and $r_{2}$ via Fisher's variance stabilizing transformation $z=1 / 2 * \ln [(1+r) /(1-r)]$ and then calculate the difference: $z_{f}=\left(z_{1}-z_{2}\right) / \operatorname{sqrt}\left(1 /\left(n_{1}-3\right)+1 /\left(n_{2}-3\right)\right)$

- The difference is approximately standard normal distribution.

- If the absolute value of the difference is greater than 1.96 (assuming 95\% confidence interval) then we can reject the null of equal correlations. 


\begin{tabular}{lrr}
\hline Table 4 Difference in correlation and p-value & & \\
\hline Variables (X\&Y) & Difference in correlation $(\mathrm{z})$ & P-value \\
\hline Private Consumption & -1.92 & 0.054 \\
Investment and ouput & -2.61 & $0.0089^{*}$ \\
CPI and output & -0.77 & 0.44 \\
Exports and output & -0.88 & 0.37 \\
Imports and output & -3.49 & $0.0004^{*}$ \\
Government expenditure and output & -1.15 & 0.25 \\
Nominal exchange rate & 2.08 & $0.037^{*}$ \\
Net exports & 3.63 & $0.000278^{*}$ \\
\hline
\end{tabular}

For private consumption, CPI, exports and government expenditure, the test results are not significant. This implies that the nature of correlation of these variables with output does not change between the pre and post reform period.

\section{Robustness Checks}

In this section we perform robustness checks to test the validity of our results.

\subsection{Stylised Facts with Quarterly Data}

In this section we present the results with quarterly data to check whether the results are consistent with results for the post-reform period in the annual data. The quarterly data for GDP is available from 1999 Q2, hence our quarterly data analysis starts from 1999 Q2. Figure 2 shows the detrended path of the key variables with output proxied by GDP. The cyclical component of the GDP series is placed in each panel of the figure to gauge the relative volatility and co-movement of each series in question with the reference series.

Business cycle stylised facts for key variables are provided in Table 5 . 
Figure 2 De-trended path of key variables with GDP
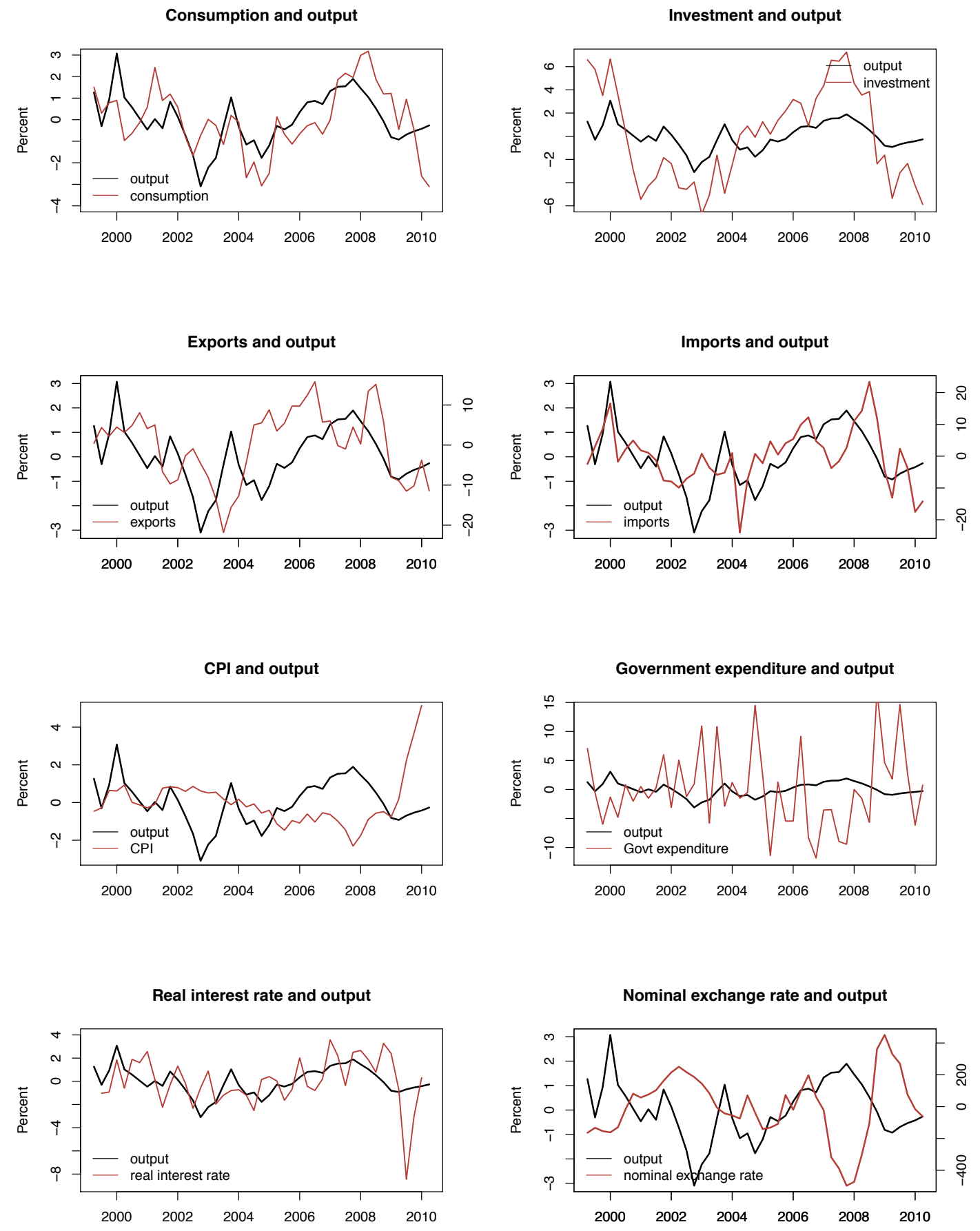
Table 5 Business cycle stylised facts using quarterly data (1999 Q2-2010 Q2)

\begin{tabular}{lrrrr}
\hline & $\begin{array}{r}\text { Std. } \\
\text { dev. }\end{array}$ & $\begin{array}{r}\text { Rel. std. } \\
\text { dev. }\end{array}$ & $\begin{array}{r}\text { Cont. } \\
\text { corr. }\end{array}$ & Persistence \\
\hline Real GDP & 1.18 & 1.00 & 1.00 & 0.73 \\
Private Consumption & 1.54 & 1.31 & 0.51 & 0.67 \\
Investment & 4.08 & 3.43 & 0.69 & 0.80 \\
CPI & 1.30 & 1.09 & -0.29 & 0.70 \\
Exports & 8.79 & 7.40 & 0.31 & 0.77 \\
Imports & 8.93 & 7.52 & 0.45 & 0.54 \\
Govt expenditure & 6.69 & 5.53 & -0.35 & 0.005 \\
Net exports & 1.24 & 1.04 & -0.15 & 0.45 \\
Real interest rate & 2.11 & 1.77 & 0.38 & 0.372 \\
Nominal exchange rate & 4.61 & 3.88 & -0.54 & 0.82 \\
\hline
\end{tabular}

Volatility: Table 5 shows private consumption as more volatile than output. This is similar to the finding for other developing economies. In general, consumption is 40 percent more volatile than income in developing economies. Conversely, in developed economies the ratio is sightly less than one on average (Aguiar and Gopinath, 2007). Table 5 reports the relative volatility of private consumption for India as 1.31 .

Prices are also more volatile than output. Again, this is consistent with the findings for developing economies. In Latin American countries, prices are six times more volatile than output (Male, 2010). The relative volatility of price level for India is 1.09

Exports and Imports exhibit significant volatilities. Higher export and import volatilities can also be seen for developed economies, though the extent of volatility is lower. For India, the relative volatility of exports and imports are 7.40 and 7.52 respectively. Net exports are also found to be more volatile than output.

Consistent with the business cycle facts for developing economies, government expenditure is more volatile than output. The relative volatility of government expenditure is 5.53. Thus on volatility, our business cycle features resemble those of developing economies.

Co-Movement: Table 5 shows investment as significantly pro-cyclical. The contemporaneous correlation of investment with output is 0.69 . The strong correlation between investment and output for India provides evidence for a growing resemblance between India and advanced economies business cycles. This is consistent with the results from annual data. 
Table 5 shows imports as pro-cyclical, while exports as mildly pro-cyclical. Again, this feature indicates resemblance between Indian and advanced economies business cycle facts.

For fiscal policy to play a stabilising role in an economy, government expenditure should be counter-cyclical. A significant difference between the annual and quarterly data analysis pertains to the correlation of government expenditure with output. For the annual analysis, the relation is counter-cyclical, though not significant. With the quarterly analysis, which pertains to recent data, we report a significant counter-cyclical relation between government expenditure and output. The correlation coefficient is -0.35 . Crucially, this is similar to the findings for developed economies.

Also consistent with the results of the annual post-reform period, nominal exchange rate is found to be counter-cyclical.

Persistence ${ }^{11}$ A central issue in business cycle research is the nature of persistence in output fluctuations. Table 5 shows persistent output fluctuations for the Indian business cycle. The magnitude of persistence is however lower compared to those of developed economies. Male (2010) finds the average persistence for developed economies to be 0.84 and for developing economies to be 0.59 . The persistence of output for India is higher than the developing economies average figure. The persistence is even higher at 0.84 if non-agricultural GDP is taken as the aggregate measure of business cycle activity. Price levels are also significantly persistent. Significant price persistence justifies the use of theoretical models with staggered prices and wages for the modeling of developing and emerging market business cycles. Other variables in Table 5 are also found to be significantly persistent (with the exception of Government expenditure and real interest rate).

In summary, the results of the quarterly data analysis broadly confirm the findings of the post-reform period using annual data. The findings support that the Indian economy is in a transition phase. While on volatility, the business cycle features resemble those of developing economies, the correlation results show growing similarity with the advanced economies business cycle.

\footnotetext{
${ }^{11}$ The results on persistence are added in quarterly data analysis.
} 


\subsection{An Alternative Detrending Method}

As another sensitivity measure, we check the robustness of our annual results to the choice of the de-trending technique. Following (Stock and Watson, 1999: Agenor et al., 2000) we use the Baxter-King to derive the business cycle properties of our macroeconomic variables. Baxter-King filter belong to the category of band-pass filters that extract data corresponding to the chosen frequency components. We are interested in extracting the business cycle components. In line with the NBER definition, the business cycle periodicity is defined as those ranging between 8 to 32 quarters.

Table 6 reports the results with the cyclical components derived from the Baxter-King filter. The results are broadly consistent with those corresponding to the Hodrick-Prescott filter. Output volatility shows a decline in the post-reform period. On correlation, the results are broadly the same. Investment becomes pro-cyclical in the post-reform period. Exports is insignificantly pro-cyclical while the cyclicality of imports is significant. Since exports is acyclical and imports are pro-cyclical, net exports are found to be counter-cyclical. Similar to the findings with the Hodrick-Prescott filter, nominal exchange rate becomes counter-cyclical in the post-reform period, though the level of significance varies.

There are some notable differences in the results related to volatility. This arises due to differences in the properties of the two filters. While the BaxterKing filter belongs to the category of band-pass filters that remove slow moving components and high frequency noise, the Hodrick-Prescott filter is an approximation to a high-pass filter that removes the trend but passes high frequency components in the cyclical part. The Baxter-King filter, however tends to underestimate the cyclical component. (Rand and Tarp, 2002) As an example, in contrast to the findings of the Hodrick-Prescott filter, the absolute volatility of private consumption declines in the post-reform period, when the Baxter-King filter is used to de-trend the variables. The statistical testing procedure shows that the difference in correlations is close to the cutoff value of 1.96, even though it is not as strong as with the Hodrick-Prescott filter.

\footnotetext{
${ }^{12}$ For a detailed comparison of the filtering procedure of Hodrick-Prescott and BaxterKing, refer to (Baxter and King, 1999)
} 
Table 6 Business cycle statistics for the Indian economy using annual data: Pre and post reform period (with Baxter-King filter)

\begin{tabular}{lcccccc}
\hline \hline & \multicolumn{3}{l}{ Pre-reform period } & $(1950-1991)$ & \multicolumn{3}{l}{ Post-reform period (1992-2009) } \\
\hline & $\begin{array}{l}\text { Std. } \\
\text { dev. }\end{array}$ & $\begin{array}{c}\text { Rel. } \\
\text { std. dev. }\end{array}$ & $\begin{array}{c}\text { Cont. } \\
\text { cor. }\end{array}$ & $\begin{array}{c}\text { Std. } \\
\text { dev. }\end{array}$ & $\begin{array}{c}\text { Rel. } \\
\text { std. dev. }\end{array}$ & $\begin{array}{c}\text { Cont. } \\
\text { cor. }\end{array}$ \\
\hline Real GDP & 1.94 & 1.00 & 1.00 & 0.95 & 1.00 & 1.00 \\
Pvt. Cons. & 1.59 & 0.81 & 0.86 & 1.05 & 1.10 & 0.84 \\
Investment & 3.49 & 1.79 & 0.22 & 3.12 & 3.26 & 0.60 \\
CPI & 4.29 & 2.20 & 0.28 & 1.51 & 1.58 & 0.28 \\
Exports & 5.99 & 3.07 & -0.03 & 6.08 & 6.35 & 0.36 \\
Imports & 8.76 & 4.49 & -0.06 & 6.15 & 6.42 & 0.47 \\
Govt expenditure & 6.39 & 3.10 & -0.17 & 3.73 & 3.90 & -0.44 \\
Net exports & 0.68 & 0.34 & 0.08 & 0.81 & 0.84 & -0.26 \\
Nominal exchange rate & 4.34 & 2.23 & 0.05 & 2.17 & 2.27 & -0.17 \\
\hline \hline
\end{tabular}

\subsection{Redefining the Sample Period}

Finally, we check the robustness of our results to a change in the sample period. To maintain uniformity in sample size we redefine the pre-reform period as starting from 1971.

Table 7 Business cycle statistics for the Indian economy using annual data: Pre (1971-1991) and post reform period

\begin{tabular}{lcccccc}
\hline \hline & \multicolumn{3}{c}{ Pre-reform period } & $(1971-1991)$ & \multicolumn{3}{c}{ Post-reform period (1992-2009) } \\
\hline & $\begin{array}{c}\text { Std. } \\
\text { dev. }\end{array}$ & $\begin{array}{c}\text { Rel. } \\
\text { std. dev. }\end{array}$ & $\begin{array}{c}\text { Cont. } \\
\text { cor. }\end{array}$ & $\begin{array}{c}\text { Std. } \\
\text { dev. }\end{array}$ & $\begin{array}{c}\text { Rel. } \\
\text { std. dev. }\end{array}$ & $\begin{array}{c}\text { Cont. } \\
\text { cor. }\end{array}$ \\
\hline Real GDP & 2.24 & 1.00 & 1.00 & 1.78 & 1.00 & 1.00 \\
Pvt. Cons. & 1.94 & 0.86 & 0.69 & 1.87 & 1.05 & 0.89 \\
Investment & 3.55 & 1.57 & 0.50 & 5.10 & 2.85 & 0.77 \\
CPI & 5.96 & 2.64 & -0.16 & 3.49 & 1.95 & 0.29 \\
Exports & 6.00 & 2.66 & 0.10 & 7.71 & 4.31 & 0.33 \\
Imports & 8.71 & 3.87 & -0.10 & 9.61 & 5.38 & 0.70 \\
Govt expenditure & 5.62 & 2.62 & 0.50 & 4.60 & 2.58 & -0.26 \\
Net exports & 0.8 & 0.3 & 0.12 & 1.1 & 0.65 & -0.69 \\
Nominal exchange rate & 5.54 & 2.46 & 0.40 & 5.35 & 3.00 & -0.48 \\
\hline \hline
\end{tabular}

Table 7 reports business cycle facts when the pre-reform period is defined as starting from 1971. The broad stylised facts remain the same. On correlation, our results remain the same as reported in Table 3 . Investment and imports become highly pro-cyclical, while net exports and nominal exchange rate turn 
counter-cyclical in the post-reform period. On volatility, we get a mixed picture. While aggregate GDP is highly volatile at 2.24 in the pre-reform period, it falls to 1.78 in the post-reform period. Other variables, with the exception of investment, exports, imports and net exports also show a fall in volatility from the pre to post reform period.

\section{Conclusion}

Documenting business cycle stylised facts forms the foundation of quantitative general equilibrium models either in the RBC or DSGE tradition. Such a study assumes greater relevance in the context of an economy like India which has undergone significant transformation since 1991. The industrial sector has been freed from capacity controls, import duties have been reduced and a reasonably conducive environment towards the global economy has evolved over the last few years. The novel aspect of this paper is to present a comprehensive set of stylized facts governing an economy in transition. We locate facts about Indian business cycles in the context of other industrial economies, as well as other emerging and developing countries.

Our main findings are as follows:

- Output volatility, as measured by the percentage standard deviation of the filtered cyclical component of GDP is considerably reduced in the post-reform period.

- Consistent with the business cycle facts for developed economies, investment becomes highly pro-cyclical in the post-reform period.

- Imports become highly pro-cyclical in the post-reform period.

- Net exports and nominal exchange rate become counter-cyclical in the post-reform period.

- The quarterly data analysis that focuses only on recent data shows government expenditure to be counter-cyclical. This feature is indicative of the growing resemblance between the Indian and the advanced economies business cycle.

This kind of study holds relevance not just for India, but for any economy that undergoes transition. An important finding is that for DSGE models to effectively incorporate the features of an economy in transition, recent data should be taken. 
Future work can use the findings of this paper to assess the extent to which DSGE models, starting with the simplest RBC model through to NewKeynesian models with labour markets and financial frictions introduced in stages, can explain business cycle fluctuations in India. Both closed and open economy models can be examined. Comparisons with a representative developed economy, say the US, can then be made. Proceeding in this way, one will be able to assess the relative importance of various frictions in driving aggregate fluctuations in India. Another avenue for future work relates to (Lucas, 1987), which pointed out that the welfare gains from eliminating business cycle fluctuations in the standard RBC model are small, and dwarfed by the gains from increased growth. While adding New Keynesian frictions significantly increases the gains from stabilization policy, they still remain small compared to the welfare gains from increased growth. However, there is relatively little work introducing long-run growth into DSGE models, and exploring the relationship between volatility and endogenous growth. This takes particular importance for India which has moved to a higher growth path in recent years, with the attendant decline in macroeconomic volatility, as documented in this paper. 


\section{References}

Agenor P, McDermott C, Prasad E (2000). "Macroeconomic fluctuations in developing countries: Some stylised facts." The World Bank Economic Review.

Aghion P, Angeletos G, Banerjee A, Manova K (2010). "Volatility and growth: Credit constraints and the composition of investment." Journal of Monetary Economics, 57(3), 246-265. ISSN 0304-3932.

Aghion P, Bacchetta P, Banerjee A (2004). "Financial development and the instability of open economies." Journal of Monetary Economics, 51, 1077-1106.

Aguiar M, Gopinath G (2007). "Emerging market business cycles: The cycle is the trend." Journal of Political Economy, 115(1).

Alper C (2002). "Business cycles, excess volatility, and capital flows: Evidence from Mexico and Turkey." Emerging Markets Finance \&6 Trade, pp. 25-58. ISSN 1540-496X.

Ambler S, Cardia E, Zimmermann C (2004). "International business cycles? What are the facts?" Journal of Monetary Economics.

Apergis N (1996). "The cyclical behaviour of prices: Evidence from seven developing countries." The Developing Economies.

Backus D, Kehoe P (1992). "International evidence on the historical properties of business cycles." The American Economic Review, 82(4), 864-888. ISSN 0002-8282.

Batini N, Gabriel V, Levine P, Pearlman J (2010). "A floating versus managed exchange rate regime in a DSGE model of India." Department of Economics, Surrey University, Discussion Papers.

Baxter M, King R (1999). "Measuring business cycles: approximate band-pass filters for economic time series." Review of Economics and Statistics, 81(4), 575-593. ISSN 0034-6535.

Bjornland H (2000). "Detrending methods and stylized facts of business cycles in Norway- an international comparison." Empirical Economics.

Boshoff W (December, 2010). "Band-pass filters and business cycle analysis: Highfrequency and medium-term deviation cycles in South Africa and what they measure ." Universeteit Stellenbosch University, Working Paper, 200.

Burns A, Mitchell W (1946). "Measuring business cycles." NBER Books.

Burnside C (1998). "Detrending and business cycle facts: A comment." Journal of Monetary Economics. 
Calderón C, Fuentes R (2006). "Complementarities between institutions and openness in economic development: Evidence for a panel of countries." Cuadernos de economía, 43, 49-80. ISSN 0717-6821.

Calderon C, Fuentes R (2010). "Characterising the business cycles of emerging economies." Policy Research Working Paper, The World Bank.

Calvo G (1998). "Capital flows and capital-market crises: the simple economics of sudden stops." Journal of Applied Economics, 1(1), 35-54.

Canova F (1998). "Detrending and business cycle facts." Journal of Monetary Economics.

Chadha B, Prasad E (1994). "Are prices countercyclical?: Evidence from the G-7." Journal of Monetary Economics, pp. 239-254.

Chakraborty S (2008). "Indian economic growth." UNU-WIDER Research Paper No. 2008/67.

Chari V, Kehoe P, McGrattan E (2007). "Business cycle accounting." Econometrica, 75(3), 781-836. ISSN 1468-0262.

Den Reijer A (2002). "International business cycle indicators, measurement and forecasting." De Nederlandsche Bank Research Memorandum.

Dua P, Banerji A (2001). "An indicator approach to business and growth rate cycles: The case of India." Indian Economic Review, 36, 55-78.

Gabriel V, Levine P, Pearlman J, Yang B (2010). "An estimated DSGE model of the Indian economy." Department of Economics, Surrey University, Discussion Papers.

Garcia-Cicco J, Pancrazi R, Uribe M (2010). "Real business cycles in emerging countries?" The American Economic Review, pp. 2510-2531.

Hodrick R, Prescott E (1997). "Postwar US business cycles: An empirical investigation." Journal of Money, Credit E Banking, 29(1).

Iacobucci A, Noullez A (2005). "A frequency selective filter for short-length time series." Computational economics, 25(1), 75-102. ISSN 0927-7099.

Jayaram S, Patnaik I, Shah A (2009). "Examining the decoupling hypothesis for India." Economic and Political Weekly, XLIV(44), 109-116.

Kaldor N (1957). "A model of economic growth." The Economic Journal, 67(268), 591-624. ISSN 0013-0133.

King R, Rebelo S (1999). "Resuscitating real business cycles." Handbook of macroeconomics, 1, 927-1007. 
Kose M, Otrok C, Whiteman C (2003). "International business cycles: World, region, and country-specific factors." American Economic Review, 93(4), 12161239. ISSN 0002-8282.

Kydland F, Prescott E (1990). "Business cycles: Real facts and a monetary myth." Real business cycles: a reader, p. 383.

Loayza N, Ranciere R, Servén L, Ventura J (2007). "Macroeconomic volatility and welfare in developing countries: An introduction." The World Bank Economic Review, 21(3), 343. ISSN 0258-6770.

Lucas R (1987). Models of business cycles. Basil Blackwell New York. ISBN 0631147918 .

Lucas RJ (1977). "Understanding business cycles." In "Carnegie-Rochester Conference Series on Public Policy," .

Male R (2010). "Developing country business cycle: Revisiting the stylised facts." Queen Mary, University of London, Working Paper No. 664.

Neumeyer P, Perri F (2005). "Business cycles in emerging economies: The role of interest rates." Journal of Monetary Economics.

Patnaik I, Sharma R (2002). "Business cycles in the Indian economy." MARGINNEW DELHI-, 35, 71-80. ISSN 0025-2921.

Ramey G, Ramey VA (1995). "Cross-country evidence on the link between volatility and growth." The American Economic Review, 85(5), 1138-1151.

Rand J, Tarp F (2002). "Business cycles in developing countries: Are they different?" World Development, 30(12), 2071-2088. ISSN 0305-750X.

Rebelo S (2005). "Business cycles." Annals of Economics and Finance, 6, 229-250.

Shah A (2008). "New issues in macroeconomic policy." Business Standard India, pp. 26-54.

Shah A, Patnaik I (2010). "Stabilising the Indian business cycle." India on growth turnpike: Essays in honour of Vijay L. Kelkar, pp. 136-154.

Stock J, Watson M (1999). "Business cycle fluctuations in US macroeconomic time series." Handbook of Macroeconomics, 1, 3-64. ISSN 1574-0048.

Uribe M, Yue V (2006). "Country spreads and emerging markets: Who drives whom?" Journal of International Economics, pp. 6-36. 


\section{A Data Definition and Sources}

\begin{tabular}{|c|c|c|}
\hline Variable & Definition & Source \\
\hline Gross domestic product & $\begin{array}{l}\text { GDP is a measure of the volume of all } \\
\text { goods and services produced by an } \\
\text { economy during a given period of time. } \\
\text { GDP is expressed at } 2004-05 \text { prices } \\
\text { and chained backwards to } 1999-2000 \text { prices. } \\
\text { The variable is expressed at factor cost }\end{array}$ & $\begin{array}{l}\text { National Accounts } \\
\text { Statistics }\end{array}$ \\
\hline Private consumption & $\begin{array}{l}\text { The Private final consumption expenditure } \\
\text { is defined as the expenditure incurred } \\
\text { by the resident households } \\
\text { on final consumption of goods } \\
\text { and services, whether made within } \\
\text { or outside economic territory. } \\
\text { The variable is expressed at } 2004-05 \text { prices } \\
\text { and chained backwards to } 1999-2000 \text { prices }\end{array}$ & $\begin{array}{l}\text { National Accounts } \\
\text { Statistics }\end{array}$ \\
\hline Gross fixed capital formation & $\begin{array}{l}\text { Gross fixed capital formation refers } \\
\text { to the aggregate of gross additions to } \\
\text { fixed assets and increase in inventories. } \\
\text { The variable is expressed at } 2004-05 \text { prices } \\
\text { and chained backwards till } 1999-2000 \text { prices }\end{array}$ & $\begin{array}{l}\text { National Accounts } \\
\text { Statistics }\end{array}$ \\
\hline Exports & $\begin{array}{l}\text { Exports of goods and services, rebased at } \\
1999-2000 \text { prices. }\end{array}$ & $\begin{array}{l}\text { National Accounts } \\
\text { Statistics }\end{array}$ \\
\hline Imports & $\begin{array}{l}\text { Imports of goods and services, rebased at } \\
1999-2000 \text { prices. }\end{array}$ & $\begin{array}{l}\text { National Accounts } \\
\text { Statistics. }\end{array}$ \\
\hline Net exports & $\begin{array}{l}\text { Exports - Imports divided by GDP at constant } \\
\text { prices }\end{array}$ & \\
\hline Consumer prices & $\begin{array}{l}\text { Consumer Price Index for Industrial } \\
\text { Workers measured at } 2001 \text { prices }\end{array}$ & $\begin{array}{l}\text { Labour Bureau, } \\
\text { Ministry of Labour } \\
\text { and Employment. }\end{array}$ \\
\hline Government expenditure & $\begin{array}{l}\text { Total expenditure of the Central Government } \\
\text { on revenue and capital accounts }\end{array}$ & $\begin{array}{l}\text { Budget documents, } \\
\text { Government of India }\end{array}$ \\
\hline Real interest rate & $\begin{array}{l}\text { 91-day treasury bill rate } \\
\text { deflated by } \\
\text { CPI inflation }\end{array}$ & $\begin{array}{l}\text { Reserve Bank } \\
\text { of India }\end{array}$ \\
\hline Nominal exchange rate & $\begin{array}{l}\text { Nominal rupee-dollar } \\
\text { exchange rate }\end{array}$ & $\begin{array}{l}\text { Reserve Bank } \\
\text { of India. }\end{array}$ \\
\hline
\end{tabular}

